\title{
In vitro efficacy of different antibiotics against contaminants of tissue-cultured 'Lakatan' banana
}

\author{
Alminda Magbalot-Fernandez , Carlito M. Hindoy Jr. and Leslie T. Ubaub
}

This study aimed to characterize the bacterial and fungal contaminants of tissue-cultured 'Lakatan' banana (Musa acuminata) and find out effective antibiotics against these contaminants. This was conducted at the University of Southeastern Philippines, Tagum-Mabini Campus from October 2015 to February 2016.

This experiment was laid out in a Completely Randomized Design (CRD) with five treatments replicated three times. The treatments were: T1-Control; T2Streptomycin (200 $\left.\mathrm{mg} \mathrm{L}^{-1}\right)$; T3-Nystatin $\left(1 \mathrm{~mL} \mathrm{~L}^{-1}\right)$; T4-Streptomycin $\left(200 \mathrm{mg} \mathrm{L}^{-1}\right)+$ Nystatin $\left(1 \mathrm{~mL} \mathrm{~L}^{-1}\right)$; and T5- Benomyl $\left(100 \mathrm{mg} \mathrm{L}^{-1}\right)$. Data were analyzed using ANOVA and compared through HSD.

Results showed that the different contaminants occurring during the initiation stage of tissue-cultured 'Lakatan' banana meriplants were composed of Rhizopus sp., an unidentified fungus, and Gram negative bacterium. Generally, $35 \%$ contamination was observed on this stage.

The result revealed that colony diameter of unidentified fungus and Rhizopus sp. were inhibited by Nystatin $\left(1 \mathrm{~mL} \mathrm{~L}^{-1}\right)$. While the bacterial clear zone inhibition was increased by Streptomycin. This study elucidated the effectivity of antibiotics, nystatin and streptomycin against bacterial and fungal contaminants of tissue-cultured 'Lakatan' banana.

Keywords: Bacteria, Fungi, Contaminants, Tissue-culture, 'Lakatan' banana, Meriplants

Department of Soil Science, Visayas State University, Baybay City, Leyte 6521-A

${ }^{2}$ Ecological Farm and Resource Management Institute, Visayas State University, Baybay City, Leyte 6521-A

${ }^{2}$ National Abaca Research Center, Visayas State University, Baybay City, Leyte 6521-A

\footnotetext{
*Corresponding Author. Address: College of Agriculture, Rizal Memorial Colleges, Inc. Davao City. Philippies 8000 ; Email: almindafernandez5@gmail.com

(c) Visayas State University, Baybay City, Leyte, Philippines
} 
Fernandez, Hindoy \& Ubaub

\section{INTRODUCTION}

Banana (Musa sapientum) is the fourth most important crop worldwide for developing countries, where they provide an important starch source (PCARRD 1992). It is one of the most essential staples in tropical areas and is produced for the local market (Frison and Sharrock 1999). According to World Trade Organization Statistics (WTO 2006), Ecuador, Philippines, and Costa Rica are the top three major exporters of dessert bananas in 2006.

'Lakatan' is the most highly priced cultivar in the Philippines and is traded locally and for the export market. It is mainly used as food supplement. It is the leading fruit crop in terms of volume, area, and value of production with the national average yield of 9.4 t ha $^{-1}$ (PCARRD 2004).

The tissue=culture technique developed by Damasco and Barba (1985) was further modified to sustain and become economically viable in vitro propagation system for banana. This technology was developed for the purpose of producing disease-free plant for wide areas. Furthermore, the tissue-cultured derived plants perform much better in terms of growth, vigor and yield. Hence, 'Lakatan' banana plantlets are now being mass produced through tissue culture.

Plant in vitro micropropagation is an aseptic technique for rapid multiplication of pest-free plant materials from organs, tissue, and cells of desirable plants (Vuylsteke and De Langhe 1985).

Microbial contamination is one of the major challenges facing plant in vitro propagation during different stages of culture processes, such as culture initiation and sub-culturing. Sub-culture process is a major source of contamination with about $5-15 \%$ of contaminants being introduced for every sub-culture (Leifert 1990). The major causes of the microbial contamination are insufficient sterilization of explants, growing media, working tools, and operators' hand (Omamor et al 2007). The principal microbial contaminants frequently reported in plant in vitro cultures are bacteria and fungi (Cassels 1996).

An application of systemic fungicides such as benomyl (benlate $\left.{ }^{\circledR}\right)$, nystatin, streptomycin and penicillin before the collection of plant materials also suppresses microbial contaminants in plant in vitro cultures (Mng'omba et al 2012). Alternatively, an incorporation of antibiotics and antifungal agents into the growth media of plant cultures has been reported to eliminate microbial contaminants (Habiba et al 2002, Reed et al 1995).

Recent studies reported that different contaminants occurred during the initiation stage of tissue-cultured 'Lakatan' banana meriplants that included Rhizopus sp., an unidentified fungus, and a Gram-negative bacterium. Generally, $35 \%$ contamination was observed on this stage (Hindoy et al 2020). Two species of fungi were also identified as contaminants of the tissue-cultured abaca in the initial stage of micropropagation. Of these genera, Chrysosporium sp. occurred most frequently (10\%), followed by Aspergillus sp. (5\%) (Cobrado and Fernandez 2016). Result of in vitro test likewise showed that Benomyl (100 $\mathrm{mg} \mathrm{L}^{-1}$ ) significantly inhibited the growth of Aspergillus sp. while Nystatin ( $\left.1 \mathrm{~mL} \mathrm{~L}^{-1}\right)$ also inhibited the growth of fungal contaminants same as Chrysosporium sp. Thus, both Benomyl (100mg L $\mathrm{m}^{-1}$ ) and Nystatin $\left(1 \mathrm{~mL} \mathrm{~L}^{-1}\right)$ can be used to inhibit growth of fungal contaminants (Cobrado and Fernandez 2017). 
In vitro efficacy of different antibiotics against contaminants of tissue-cultured

Yet no or limited studies on particular contaminants of tissue-cultured 'Lakatan' banana have been reported. Hence, this study was conducted to test the efficacy of various antibiotics in 'Lakatan' banana cultivar; to identify and characterize the contaminants of tissue-cultured 'Lakatan' banana; and to find out the most effective treatment against bacterial and fungal contaminants of tissue-cultured 'Lakatan' banana meriplants.

\section{MATERIALS AND METHODS}

\section{Duration and Location of the Study}

The study was conducted at the Tissue Culture Laboratory and Crop Research Laboratory of the University of Southeastern Philippines, Tagum-Mabini Campus, Mabini Unit, Pindasan, Mabini, Compostela Valley Province from October 2015 to February 2016.

\section{Identification and Characterization of Microbial Contaminants}

The suckers of 'Lakatan' were collected from the University of Southeastern Philippines, Mabini, Compostella Valley Province. Each sucker was cut into one to three inches' quarters. For each treatment, four to five explants (20 culture media) were used. The isolation room was maintained in aseptic condition or free from any contamination. The laminar floor was sprayed with $70 \%$ ethanol. The UV light was turned on for $30 \mathrm{~min}$ before use of the isolation room.

The media and glass wares were sterilized for $15 \mathrm{~min}$ using pressure cooker at $15 \mathrm{psi}$. The modified MS media was used and added with the different rates of antibiotics depending on the treatments used and $\mathrm{pH}$ was adjusted to 5.7 (Damasco 1985) before sterilization for $15 \mathrm{~min}$.

\section{Establishment and Stabilization of Explants in Culture}

This was done by selecting healthy suckers of 'Lakatan' used for tissue culture. Young suckers $(50-100 \mathrm{~cm})$ that were disease-free were collected. The suckers collected from the field were washed in tap water and air-dried. The upper middle portion and the outer bracts of the suckers were removed with sharp knife and the remaining basal portion was washed with commercial bleach solution. The next layers of leaves and excess corm tissues were removed to obtain a block measuring $6-8 \mathrm{~cm}$ long, $3-5 \mathrm{~cm}$ in diameter and were soaked in commercial bleach solution for $20 \mathrm{~min}$.

Under aseptic condition inside the laminar flow, superfluous tissues were removed by trimming away the tightly overlapping leaf sheaths and bases, exposing the meristemic cells in between the leaf bases. The shoot tip was decapitated and a block of tissue about $1.5 \mathrm{~cm}^{3}$ was excised, divided into four quarters and inoculated unto the multiplication medium. The cultures were labeled, transferred to the growing culture room, and incubated at $26^{\circ} \mathrm{C}$ with $16 \mathrm{~h}^{\prime}$ light/dark cycle for four weeks. During incubation in the growth room, cultures were inspected for contamination and mortality of explant tissues. 
Fernandez, Hindoy \& Ubaub

\section{Isolation of Bacterial and Fungal Contaminants}

Each of the sterilized explant was placed in a bottle of solidified nutrient agar medium without antibiotic. Detectable bacterial and fungal contaminants were isolated and sub-cultured into the fresh medium two to four days after incubation. The bacterial isolates were cultivated by streaking into fresh culture medium and incubated at $30-32^{\circ} \mathrm{C}$ for three days. For fungi, culture disk was transferred to fresh culture medium and incubated at $30-32^{\circ} \mathrm{C}$ for three to five days.

\section{Purification of Bacterial and Fungal Contaminants}

Detected fungal contaminants with highest frequency of occurrence were inoculated unto Potato Dextrose Agar (PDA) while bacteria were inoculated in Potato Sucrose Agar. The isolates were purified by series of transfers to fresh culture medium. Identification of fungal contaminants was done four to seven days after transferring into fresh medium when pure cultures were obtained. Bacterial contaminants were preceded to Gram staining after two to three days to identify the bacteria that are Gram positive or Gram negative.

\section{Gram Staining Procedure}

This was done by placing the slide with heat-fixed smear on staining tray. The smear was flooded gently with crystal violet and was allowed to stand for one minute; the slide was tilted slightly and gently rinsed with tap water or distilled water using a wash bottle. The smear was gently flooded with Gram's iodine and left to stand for one minute. The smear appeared and the purple circle on the slide was decolorized using $95 \%$ ethyl alcohol or acetone. The slide was tilted slightly and applied with alcohol drop by drop for five to ten seconds until the alcohol ran almost clear. Care was done not to overdecolorize the slide. Then it was immediately rinsed with water. It was gently flooded with safranin to counter-stain and let stand for $45 \mathrm{~s}$. The slide was tilted slightly and gently rinsed with tap water or distilled water using a wash bottle. Then slides were blot dried with bibulous paper. Lastly, smear was viewed using a light-microscope under oil-immersion. Gram negative bacteria appeared red or pink following a Gram stain procedure due to the effects of the counterstain (for example safranin), and Gram-positive bacteria appeared blue violet.

\section{Bioefficacy Test of Microbial Contaminants}

The experiment was laid-out in Completely Randomized Design (CRD) with five treatments replicated three times. There were five plates per replicate for a total of 75 plates. The treatments were: T1- Control (No treatment); T2-

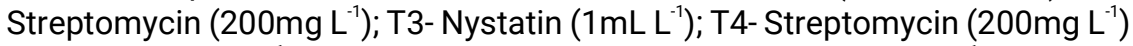
+ Nystatin (1 $\left.\mathrm{mL} \mathrm{L}^{-1}\right)$; and T5- Benomyl (Chemical check, $\left.100 \mathrm{mg} \mathrm{L}^{-1}\right)$. Nystatin has been a useful antifungal agent since the 1950s. It is a broad-spectrum antifungal agent which is active in vitro and in vivo against Aspergillus sp., Candida sp., $C$. neoformans, and $H$. capsulatum. Streptomycin remains the 
In vitro efficacy of different antibiotics against contaminants of tissue-cultured

most reliable and commercially effective control product available against diseases.

The potato tubers were washed, diced $(250 \mathrm{~g})$, placed in casserole, and simmered in $500 \mathrm{~mL}$ distilled water for $15-20$ min until soft. The potato broth was decanted thru gauze cloth into baker and set aside. The previously soaked shredded agar $(20 \mathrm{~g})$ were melted in $500 \mathrm{~mL}$ water and sucrose and constantly stirred. The sugar $(10 \mathrm{~g})$ and agar solution were added to potato broth. The volume was restored to one liter and dispensed into suitable containers.

\section{Antibiotic Sensitivity Testing for Fungi}

Poisoned Food Technique was done by cultivating the test organism on a medium containing the test chemical and then measuring its growth. The treatment was incorporated and mixed well with potato dextrose agar at about $50^{\circ} \mathrm{C}$ and poured into culture plates using $10 \mathrm{~mL}$ per plate. The poisoned medium was seeded in the center with a $5-10 \mathrm{~mm}$ diameter agar disk of the test fungus. After an incubation period, radial growth was measured from edge to edge.

\section{Antibiotic Sensitivity Testing for Bacteria}

Kirby-Bauer Disk Diffusion Test method is the most common antibiotic resistance/susceptibility testing. Materials used were test tube rack, forceps, sterile swabs, Potato Sucrose Agar (PSA), plates and antibiotics for the testing and filter paper disks. The agar plates were labeled and marked using dots where the antibiotic disks were placed. The disks were submerged into different antibiotics according to treatments and allowed to dry at room temperature. The plates were inoculated with first bacterium using aseptic technique. The swab was wet with the bacterial broth culture, and the plate surface was thoroughly swabbed, making sure to cover the entire surface. The plates were turned approximately 60 degrees (Bauer et al 1959).

One antibiotic disk was placed unto the surface of the agar, using aseptic technique. The tip of the forceps was heated by placing unto alcohol lamp for five to ten seconds. Then, the forceps were cooled by waving them in the air for about ten seconds. The test disk was carefully picked up with the forceps and gently placed in the appropriate spot on the agar surface. To ensure that the disk was flat on the agar, it was gently pushed down with the forceps. The tip of the forceps was reheated as above to kill any bacteria. The same procedure was repeated for the other treatments. Plates were inoculated in room temperature (Hudzicki 2009).

\section{Data Gathered}

Number of days to appearance of microbial contaminants was taken by counting the number of days that the fungal and bacterial contaminants appeared on the test medium.

Percentage of contaminated growing media was computed by counting the contaminated culture media from the total culture and computed using the following formula:

$$
\text { Percent Contamination }=\frac{\text { No. of contaminated culture media }}{\text { Total } \text { no. of culture media }} \times 100
$$


Frequency of Occurrence of Contaminants in Culture medium was determined by the number of times a contaminant appeared on the culture medium. Fungal contaminants were identified according to their genera while bacterial contaminants were identified either as Gram positive or Gram negative.

Bacterial contaminants were described on the bases of their colony form, colony color, colony texture, colony elevation, colony margin or edge, and colony color. Colony form may be circular, irregular, filamentous and rhizoid or curled. Colony texture may be dry, moist, mucoid, brittle, viscous, butyrous (buttery) etc. Colony elevation was described on the side view of a colony as elevated, convex, concave, umbonate/umbilicate. Colony margin or edge may be entire, undulate, crenated, fimbriate or curled. Colony color could be yellow, white, pink, green etc. Colony structure could be opaque, translucent, or transparent.

Fungal contaminants were described based on their colony form, colony elevation, colony margin, colony surface, colony texture, and colony color. Colony form may be described as circular, irregular, filamentous, and rhizoid. Colony elevation may be raised, convex, flat, and crater form. Colony margin may be described as entire, undulate, filiform, curled, and lobate. Colony surface could be described as smooth, glistening, rough, wrinkled, or dull; colony texture, as cottony, dry, etc. Colony color could be white, buff, red, black, purple, etc.

Clear Zone of Inhibition on the Growth of the Bacterium was determined by measuring the diameter of the clear zone of inhibition from edge to edge twice across at the longest and shortest edge of the disc in millimeter. Data were gathered at 48 and $72 \mathrm{~h}$ of incubation.

The colony diameter of fungus was measured from edge to edge twice at the longest and shortest edge using a ruler and expressed in millimeter. Data were gathered after three days' inoculation until the control plates were full of contaminants.

The Growth Increment of Contaminants was determined by subtracting the final colony diameter from initial growth of fungus and for bacteria by subtracting the final clear zone of inhibition diameter from initial clear zone of inhibition diameter.

The data were analyzed using Analysis of Variance (ANOVA) and the differences among the treatment means were compared using Honest Significant Difference (HSD) test when significant findings were obtained from ANOVA.

\section{RESULTS AND DISCUSSION}

\section{Identification and Characterization of Microbial Contaminants}

Bacterial and fungal contaminants were observed during the initial stage of micro propagation of tissue-cultured 'Lakatan' banana (Table 1). After 11 days from initiation, the fungal contaminant that appeared was suspected as Rhizopus $s p$. in two culture media. The species of Rhizopus are very common laboratory contaminants and are weak parasites as well as saprophytes to various common substrates (O'Donnel 1979). At 13 days after micropropagation, unidentified fungus appeared in three bottles and also bacterial contaminants appeared in two bottles with white/transparent morphological appearance. 
In vitro efficacy of different antibiotics against contaminants of tissue-cultured

Table 1. Percentage, occurrence and days appeared of microbial contamination by different microorganism during initiation stage of tissue-cultured 'Lakatan' banana in 20 culture media.

\begin{tabular}{lccc}
\hline Suspected Contaminants & $\begin{array}{c}\text { Percentage of } \\
\text { Contaminated Culture } \\
\text { Media }\end{array}$ & $\begin{array}{c}\text { Frequency of } \\
\text { Occurrence }\end{array}$ & Days Appeared \\
\hline Rhizopus sp. & $10 \%$ & $2 / 20$ & $11^{\text {th }}$ day \\
Unidentified Fungus & $15 \%$ & $3 / 20$ & $13^{\text {th }}$ day \\
Gram Negative Bacteria & $10 \%$ & $3 / 20$ & $13^{\text {th }}$ day \\
Total & $35 \%$ & $7 / 20$ & - \\
\hline
\end{tabular}

Table 1 reveals the percentage of contaminated growing media of tissue cultured 'Lakatan' banana. After 30 days of initiation stage of tissue-cultured 'Lakatan' banana, the result showed $10 \%$ of suspected Rhizopus sp., $15 \%$ of unidentified fungus, and $10 \%$ of bacterial contaminants for a total of $35 \%$ contamination. This observation coincides with the encountered problem of the Tissue Culture Laboratory of the University of Southeastern Philippines, based on personal communication with the laboratory technicians.

Sub-culture process is a major source of contamination with about $5-15 \%$ of contaminants being introduced for every subculture (Leifert 1990). The major cause of the microbial contamination is insufficient sterilization of explants, growth media, working tools, and operators' hands (Omamor et al 2007).

In terms of frequency of occurrence of contaminants of tissue-cultured 'Lakatan' banana, suspected Rhizopus sp. was observed twice, while the unidentified fungus appeared thrice in the 20 culture media. It was also noticed that bacterial contaminants occurred twice in 20 culture media.

The first fungal contaminants appeared in tissue-cultured 'Lakatan' banana was identified as Rhizopus $s p$. The unidentified fungal contaminant in tissue-cultured 'Lakatan' banana has almost the same morphological appearance as Penicillium sp. The bacterial contaminants appeared in tissue-cultured 'Lakatan' is Gram negative bacteria.

According to the study of Legatt et al (1994), approximately 31 micro-organisms from 10 different plant cultivars growing in micro-propagation have been isolated identified and characterized, with Yeasts, Corynebacterium sp. and Pseudomonas $s p$. being predominant.

The Rhizopus sp. mycelia have aerial and creeping type stolons developed rhizoids at certain points or upon contact with solid base; sporangiospores long and upright; sporangia spherical containing minute aplanospores which are easily dispersed with the breaking of the sporangiosphores envelope (O'Donnel 1979).

The unidentified fungal contaminant has conidiophores arising from the mycelium or less often synnemata, branched near the apex to form a brush-like conidia-bearing apparatus, ending in phialides which pinch off conidia celled, mostly globose or ovoid, produced basipetally.

The bacterial contaminants that appeared were Gram negative bacteria which are bacteria that do not retain the crystal violet dye in the Gram stain protocol. Gram negative bacteria appeared red or pink following a Gram stain procedure due to the effects of the counterstain like safranin. 
The principal microbial contaminants frequently reported in plant in vitro cultures are bacteria and fungi (Cassels 1996). Pseudomonas syringae, Bacillus licheniformis, Bacillus subtilis, Cornebacterium sp. and Erwinia sp. have been reported to be the major bacterial contaminants in plant tissue cultures (Odutayo et al 2004) while the main fungal contaminants frequently observed in plant tissue cultures are Alterneria tenius, Aspergillus niger, Aspergillus fumigatus and Fusarium culmorum (Odutayo et al 2004, Odutayo et al 2007). Recent studies also reported that different contaminants occurred during the initiation stage of tissue-cultured 'Lakatan' banana; meriplants were composed of Rhizopus sp., an unidentified fungus, and Gram-negative bacterium with $35 \%$ contamination (Hindoy et al 2020). Two species of fungi were Chrysosporium sp. like fungus which occurred most frequently $(10 \%)$, followed by Aspergillus $s p$. (5\%) as fungal contaminants of the tissue-cultured abaca in the initial stage of micropropagation (Cobrado and Fernandez 2016).

\section{Bioefficacy Test of Microbial Contaminants}

Colony diameter of Rhizopus $s p$. was significantly affected by different antibiotic agents against bacterial and fungal contaminants in tissue-cultured 'Lakatan' banana at three to four days after incubation (Table 2).

Table 2. Average colony diameter ( $\mathrm{mm}$ ) of Rhizopus sp. as affected by different antibiotic agents against bacterial and fungal contaminants of tissue-cultured 'Lakatan' banana in vitro at three to four days after incubation (DAl).

\begin{tabular}{|c|c|c|}
\hline Treatments & $\left.3 \mathrm{DA}\right|^{\star \star *}$ & $4 \mathrm{DA} \mid * \star$ \\
\hline T1- Control (No treatment) & $89.58^{\mathrm{c}}$ & $90.00^{c}$ \\
\hline T2- Streptomycin $\left(200 \mathrm{mg} \mathrm{L}^{-1}\right)$ & $88.83^{\mathrm{C}}$ & $89.91^{\mathrm{c}}$ \\
\hline T3- Nystatin $\left(1 \mathrm{~mL} \mathrm{~L}^{-1}\right)$ & $10.50^{\mathrm{a}}$ & $14.67^{\mathrm{a}}$ \\
\hline T4- Streptomycin $\left(200 \mathrm{mg} \mathrm{L}^{-1}\right)+$ Nystatin $\left(1 \mathrm{~mL} \mathrm{~L}^{-1}\right)$ & $10.67^{\mathrm{a}}$ & $11.92^{\mathrm{a}}$ \\
\hline T5- Benomyl (Chemical check)100 $\mathrm{mg} \mathrm{L}^{-1}$ ) & $17.67^{\mathrm{b}}$ & $35.16^{\mathrm{b}}$ \\
\hline CV (\%) & 1.37 & 2.14 \\
\hline
\end{tabular}

At 4th day, application of Nystatin $\left(1 \mathrm{~mL} \mathrm{~L}^{-1}\right)$ and Streptomycin $\left(200 \mathrm{mg} \mathrm{L}^{-1}\right)+$ Nystatin $\left(1 \mathrm{~mL} \mathrm{~L}^{-1}\right)$ significantly inhibited the growth of Rhizopus sp. (Figure 1). The highest colony diameter was observed in control and application of Streptomycin.

Figure 2 shows the colony growth increment at third to fourth day after incubation. In day three, it was observed that the control and Streptomycin $(200 \mathrm{mg}$ $\mathrm{L}^{-1}$ ) showed the highest increment or rapid mycelial development that almost filled the entire plate of its growth; the lowest growth increment was observed in Nystatin $\left(1 \mathrm{~mL} \mathrm{~L}^{-1}\right)$ and Streptomycin $\left(200 \mathrm{mg} \mathrm{L}^{-1}\right)+\operatorname{Nystatin}\left(1 \mathrm{~mL} \mathrm{~L}^{-1}\right)$. 
In vitro efficacy of different antibiotics against contaminants of tissue-cultured

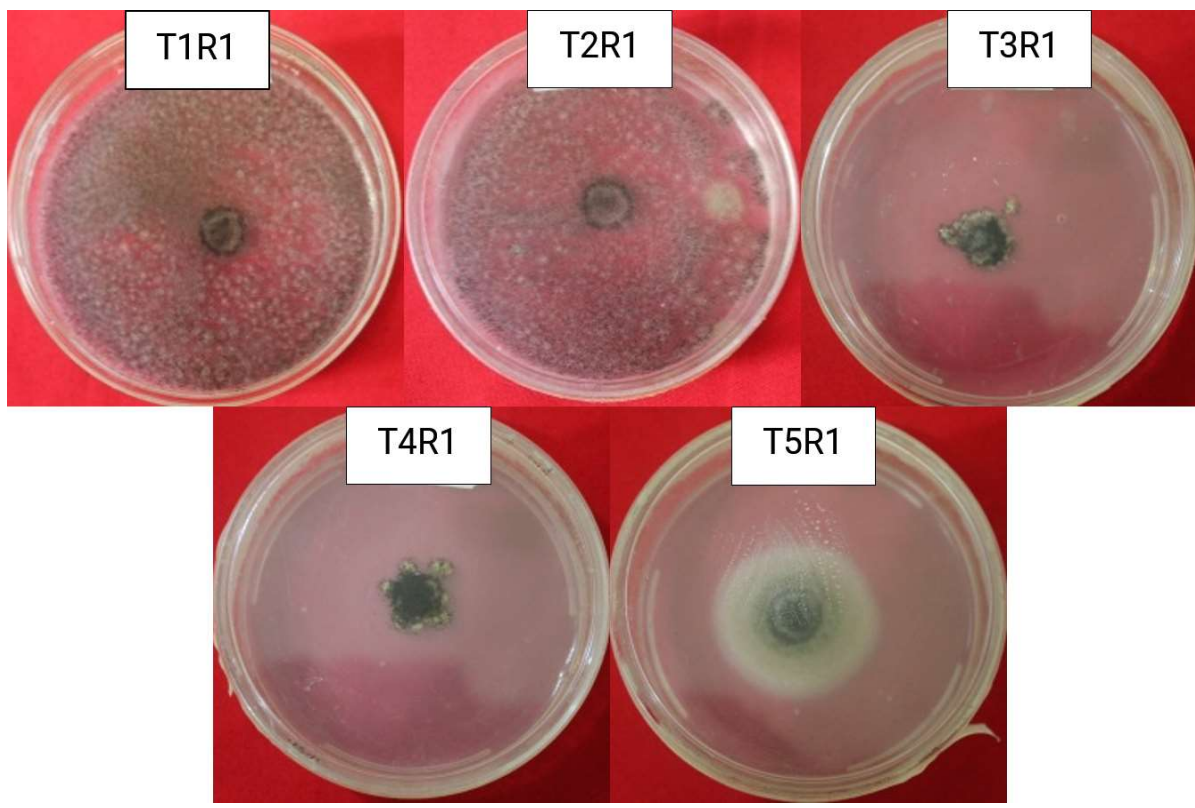

Figure 1. The inhibitory effect exhibited by different antibiotics against Rhizopus sp. of tissuecultured 'Lakatan' banana after four days of incubation. T1- Control; T2-Streptomycin $(200 \mathrm{mg}$ $\left.\mathrm{L}^{-1}\right)$; T3-Nystatin $\left(1 \mathrm{~mL} \mathrm{~L}^{-1}\right)$; T4- Streptomycin $\left(200 \mathrm{mg} \mathrm{L}^{-1}\right)+$ Nystatin $\left(1 \mathrm{~mL} \mathrm{~L}^{-1}\right)$; and T5- Benomyl (100mg L $\mathrm{m}^{-1}$.

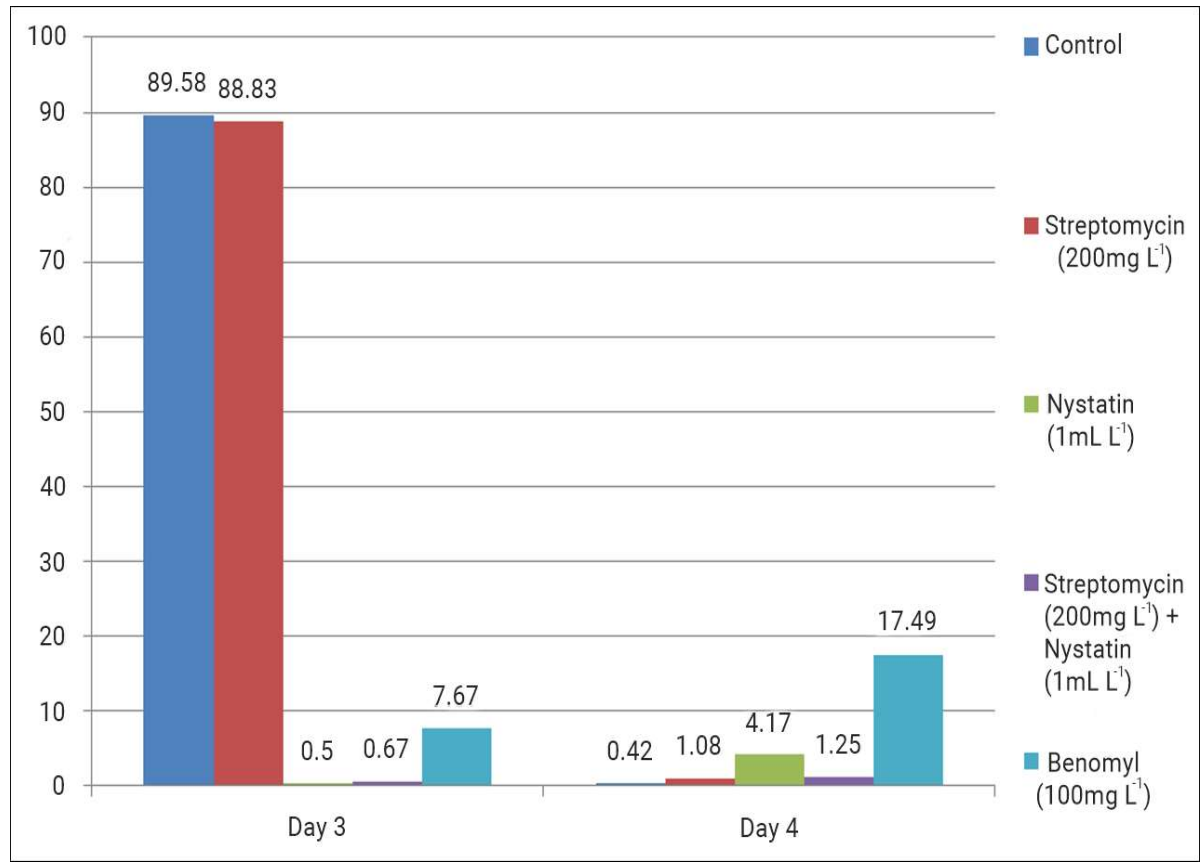

Figure 2. Increment in colony diameter $(\mathrm{mm})$ of Rhizopus sp. as affected by different antibiotic agents against bacterial and fungal contaminants of tissue-cultured 'Lakatan' banana in vitro at three to four days after incubation. 
Table 3 and Figure 3 shows the means of colony diameter of unidentified fungus as affected by different antibiotic agents against bacterial and fungal contaminants of tissue-cultured 'Lakatan' banana at seven days after incubation (DAI). The analysis of variance showed that the growth of fungi was significantly different among treatments. After three to seven days of incubation, Nystatin $(1 \mathrm{~mL}$ $\mathrm{L}^{-1}$ ) were found effective in controlling the growth of unidentified fungus compared to control. Average colony diameter of Nystatin and Benomyl (chemical check) was significantly different.

Table 3. Average colony diameter $(\mathrm{mm})$ of Unidentified Fungus as affected by different antibiotic agents against bacterial and fungal contaminants of tissue-cultured 'Lakatan' banana in vitro at three to seven days after incubation

\begin{tabular}{|c|c|c|c|c|c|}
\hline Treatments & $\left.3 \mathrm{DA}\right|^{\star *}$ & $4 \mathrm{DAl}^{\star \star}$ & $\left.5 \mathrm{DA}\right|^{\star \star}$ & $6 \mathrm{DAl}{ }^{\star *}$ & $7 \mathrm{DA} I^{\star \star}$ \\
\hline T1-Control (No treatment) & $70.67^{c}$ & $77.58^{d}$ & $80.50^{d}$ & $84.33^{d}$ & $90.00^{d}$ \\
\hline T2-Streptomycin (200 $\left.\mathrm{mg} \mathrm{L}^{-1}\right)$ & $66.33^{c}$ & $71.83^{\mathrm{cd}}$ & $75.58^{\mathrm{cd}}$ & $80.58^{\mathrm{cd}}$ & $86.75^{d}$ \\
\hline T3-Nystatin $\left(1 \mathrm{~mL} \mathrm{~L}^{-1}\right)$ & $10.17^{a}$ & $10.55^{\mathrm{a}}$ & $10.75^{\mathrm{a}}$ & $11.00^{\mathrm{a}}$ & $11.17^{\mathrm{a}}$ \\
\hline $\begin{array}{l}\text { T4-Streptomycin }\left(200 \mathrm{mg} \mathrm{L}^{-1}\right)+ \\
\text { Nystatin }\left(1 \mathrm{~mL} \mathrm{~L}^{-1}\right)\end{array}$ & $45.08^{b}$ & $55.67^{c}$ & $61.50^{c}$ & $66.58^{c}$ & $72.92^{c}$ \\
\hline $\begin{array}{l}\text { T5-Benomyl (Chemical } \\
\text { check) } 100 \mathrm{mg} \mathrm{L}^{-1} \text { ) }\end{array}$ & $30.67^{b}$ & $38.17^{b}$ & $44.17^{b}$ & $48.25^{b}$ & $54.67^{\mathrm{b}}$ \\
\hline CV (\%) & 16.83 & 12.29 & 10.37 & 9.36 & 7.32 \\
\hline
\end{tabular}

** $=$ highly significant at $1 \%$ level

Means in column followed by the same letter superscript are not significantly different at $1 \%$ level of probability using HSD

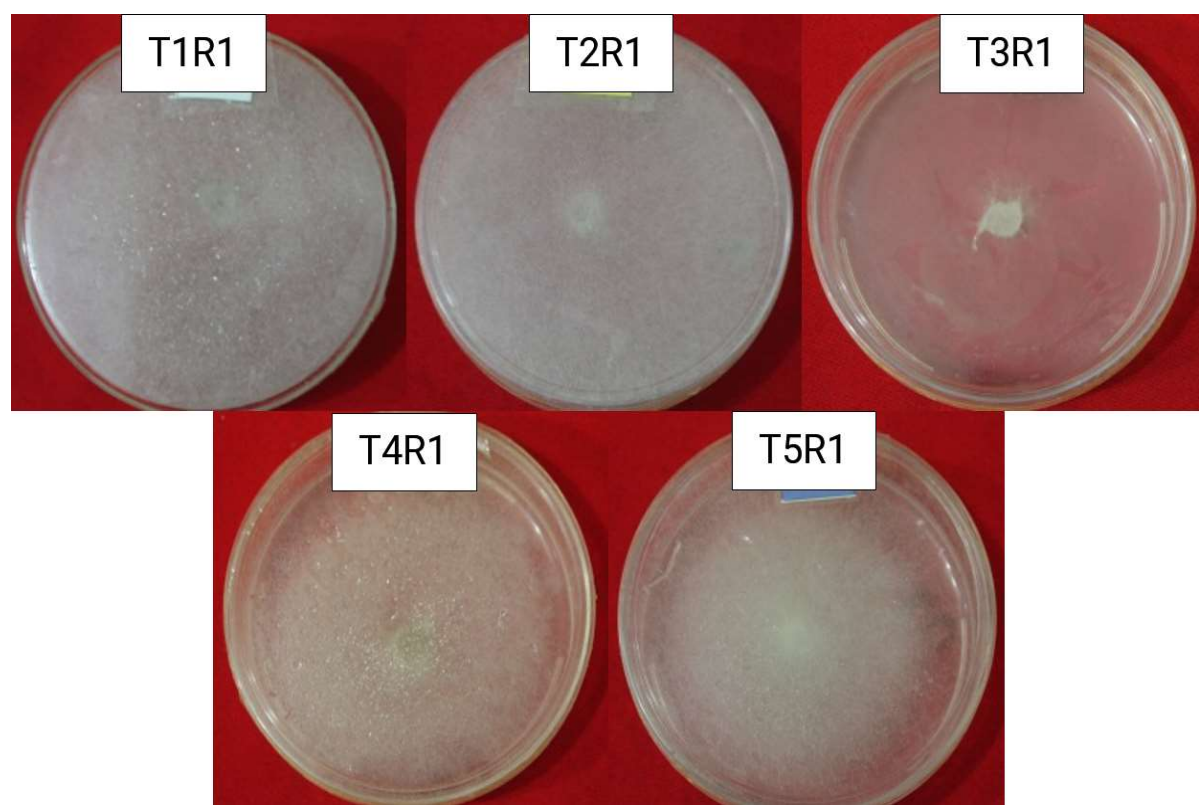

Figure 3. The inhibitory effect exhibited by different antibiotics against Unidentified Fungus of tissue-cultured 'Lakatan' banana after seven days of incubation. T1-Control; T2-Streptomycin (200 $\left.\mathrm{mg} \mathrm{L}^{-1}\right)$; T3-Nystatin $\left(1 \mathrm{~mL} \mathrm{~L}^{-1}\right)$; T4- Streptomycin $\left(200 \mathrm{mg} \mathrm{L}^{-1}\right)+$ Nystatin $\left(1 \mathrm{~mL} \mathrm{~L}^{-1}\right)$; and T5Benomyl (100mg L-1). 
In vitro efficacy of different antibiotics against contaminants of tissue-cultured

Figure 4 reveals the colony growth increment of unidentified fungus in tissuecultured 'Lakatan' banana at seven days after incubation. It was observed that the lowest growth increment was on treatment with Nystatin. The slowest colony development at three to seven days after incubation was on the medium treated with Nystatin.

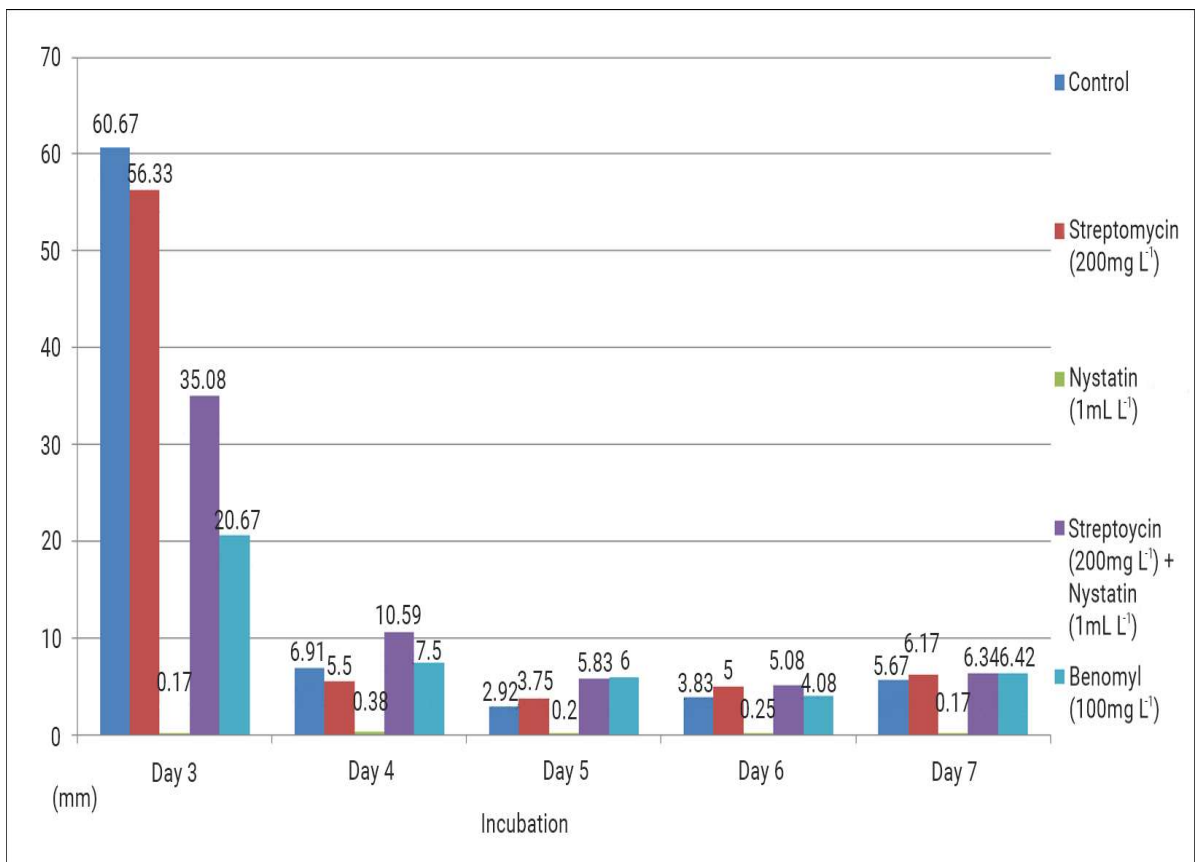

Figure 4. Increment in colony diameter $(\mathrm{mm})$ of Unidentified Fungus as affected by different antibiotic agents against bacterial and fungal contaminants of tissue-cultured 'Lakatan' banana in vitro at three to seven days after incubation

Table 4 and Figure 5 show the mean of clear zone inhibition diameter of bacteria as affected by different antibiotic agents against bacterial and fungal contaminants of tissue-cultured 'Lakatan' banana in vitro at 24,48 , and $72 \mathrm{~h}$ after inoculation (HAl). Analysis of variance showed a highly significant difference among treatments.

Table 4. Average clear zone inhibition diameter $(\mathrm{mm})$ of Gram negative bacteria as affected by different antibiotics against bacterial and fungal contaminants of tissue-cultured 'Lakatan' banana in vitro at 24,48 and $72 \mathrm{~h}$ after incubation (HAI).

\begin{tabular}{|c|c|c|c|}
\hline Treatments & $24 \mathrm{HAl}{ }^{\star *}$ & $48 \mathrm{HAl}^{\star *}$ & $72 \mathrm{HAl}$ *夫 \\
\hline T1- Control (No treatment) & $8.00^{\mathrm{b}}$ & $8.00^{b}$ & $8.00^{\mathrm{b}}$ \\
\hline T2- Streptomycin $\left(200 \mathrm{mg} \mathrm{L}^{-1}\right)$ & $23.73^{\mathrm{a}}$ & $27.80^{\mathrm{a}}$ & $28.00^{\mathrm{a}}$ \\
\hline T3- Nystatin $\left(1 \mathrm{~mL} \mathrm{~L}^{-1}\right)$ & $8.00^{\mathrm{b}}$ & $8.00^{\mathrm{b}}$ & $8.00^{\mathrm{b}}$ \\
\hline T4- Streptomycin $\left(200 \mathrm{mg} \mathrm{L}^{-1}\right)+$ Nystatin $\left(1 \mathrm{~mL} \mathrm{~L}^{-1}\right)$ & $28.07^{\mathrm{a}}$ & $29.47^{\mathrm{a}}$ & $29.67^{\mathrm{a}}$ \\
\hline T5- Benomyl (Chemical check)100mg L-1) & $8.00^{\mathrm{b}}$ & $8.00^{b}$ & $8.00^{b}$ \\
\hline CV (\%) & 12.72 & 9.65 & 9.77 \\
\hline
\end{tabular}

** = highly significant at $1 \%$ level

Means in column followed by the same letter superscript are not significantly different at $1 \%$ level of probability using HSD 


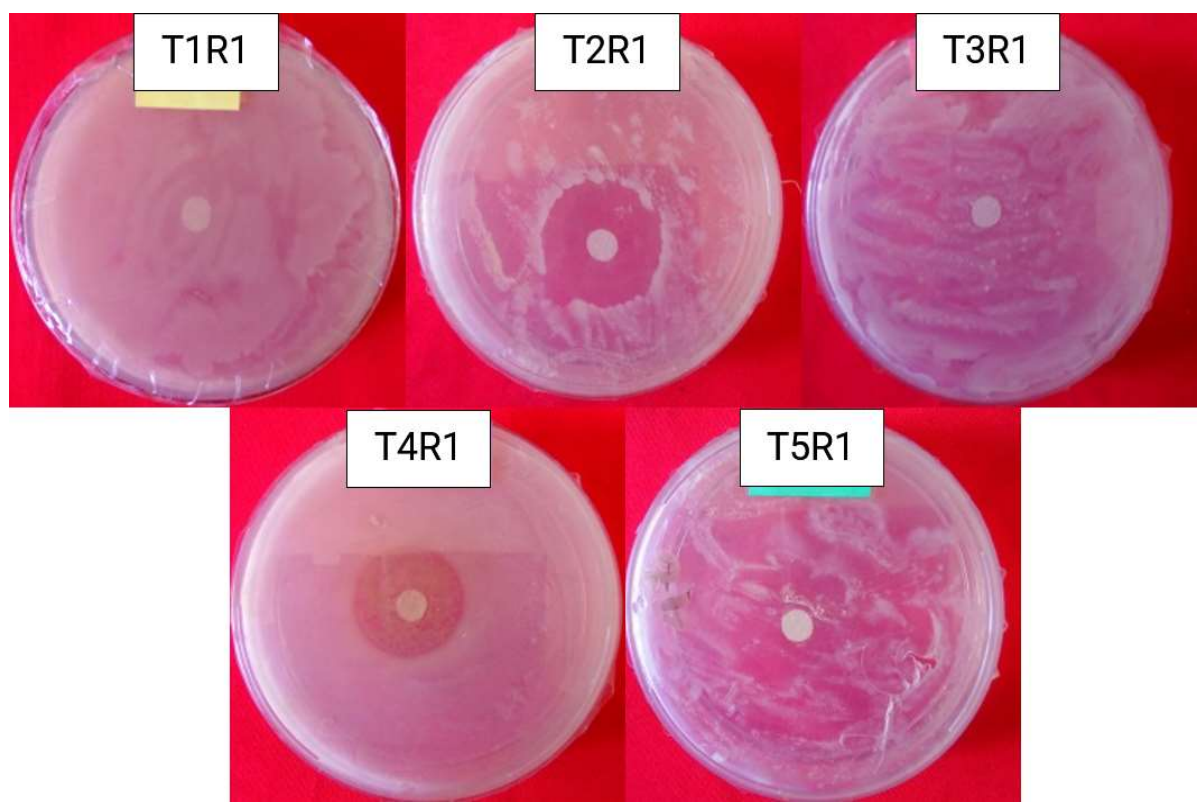

Figure 5. The inhibitory effect exhibited by different antibiotics against Gram negative bacteria of tissue-cultured 'Lakatan' after $72 \mathrm{~h}$ of incubation. T1- Control; T2-Streptomycin (200mg L-1); T3Nystatin $\left(1 \mathrm{~mL} \mathrm{~L}^{-1}\right)$; T4-Streptomycin $\left(200 \mathrm{mg} \mathrm{L}^{-1}\right)+\operatorname{Nystatin}\left(1 \mathrm{~mL} \mathrm{~L}^{-1}\right)$; and T5- Benomyl $\left(100 \mathrm{mg} \mathrm{L}^{-1}\right)$.

At 24 to $72 \mathrm{HAl}$, application of Streptomycin and Streptomycin + Nystatin were found effective for inhibitory action against bacterial contaminants.

Figure 6 shows the clear zone inhibition increment of gram-negative bacteria in tissue-cultured 'Lakatan' banana at 24 to $72 \mathrm{~h}$ of incubation. It was noticed that the most effective treatment that showed higher clear zone inhibition was on medium treated with Streptomycin and Streptomycin + Nystatin.

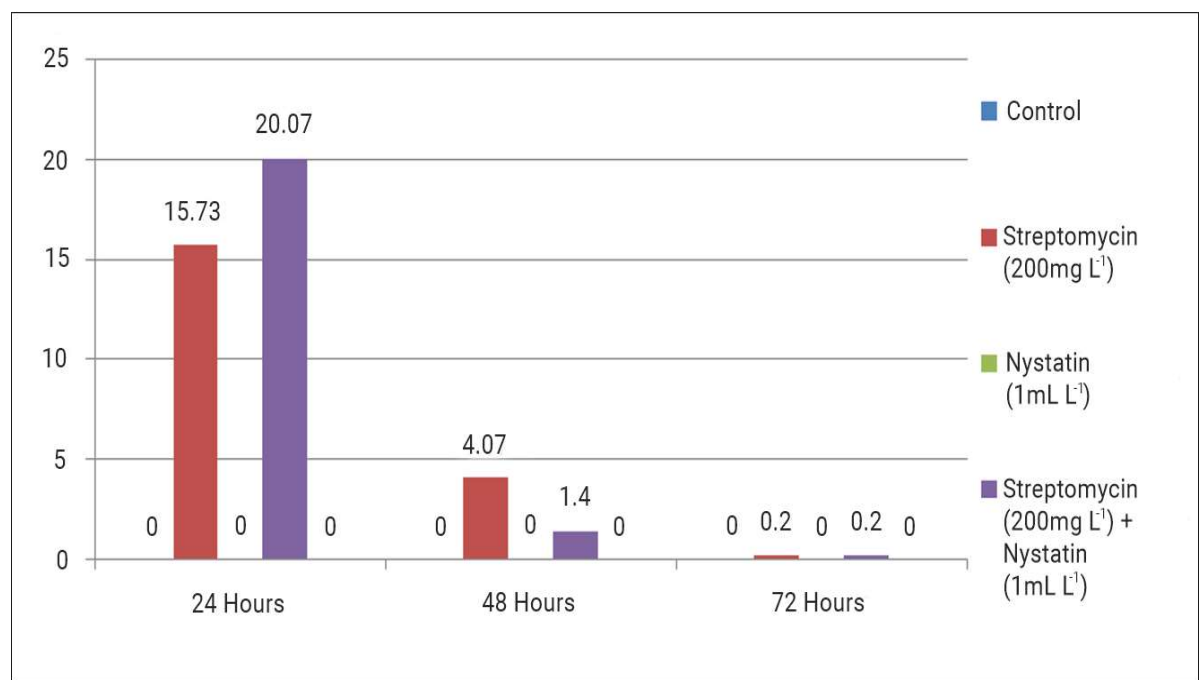

Figure 6. Increment in clear zone inhibition diameter $(\mathrm{mm})$ of Gram negative bacteria as affected by different antibiotics against bacterial and fungal contaminants of tissue-cultured 'Lakatan' banana in vitro at 24,48 and $72 \mathrm{~h}$ after incubation (HAl). 
In vitro efficacy of different antibiotics against contaminants of tissue-cultured

Application of Nystatin is significantly effective than chemical check Benomyl. Results imply that Nystatin $1 \mathrm{~mL} \mathrm{~L}^{-1}$ and Streptomycin $200 \mathrm{mg} \mathrm{L}^{-1}+$ Nystatin $1 \mathrm{~mL} \mathrm{~L}^{-1}$ showed inhibitory effect on the mycelial growth of Rhizopus. This further supports that Nystatin binds to ergosterol, a major component of the fungal cell membrane. When present in sufficient concentrations, it forms pores in the membrane that lead to K+ leakage, acidification, and death of the fungus (Hammond 1977).

This result coincides with the study of Wallace et al (1997) that Nystatin has demonstrated activity against Candida albicans, Cryptococcus neoformans, Histoplasma capsulatum and Coccidioides immitis in animals and antifungal activity against $C$ andida, Aspergillus, Histoplasma and Coccidioides infections in humans. According to Johnson and Stockwell (1998), Nystatin has been a useful antifungal agent since the 1950s and indicated that nystatin is a broad-spectrum antifungal agent which is active in vitro and in vivo against Aspergillus sp., Candida sp. and $C$. neoformans. Nystatin is also effective against $H$. capsulatum both in vitro and in vivo. Another vitro test likewise showed that Benomyl (100 $\mathrm{mg} \mathrm{L}^{-1}$ ) significantly inhibited the growth of Aspergillus sp. while Nystatin $\left(1 \mathrm{~mL} \mathrm{~L}^{-1}\right)$ also inhibited the growth of fungal contaminants same as Chrysosporium $\mathrm{sp}$. Thus, both Benomyl and Nystatin can be used to inhibit growth of fungal contaminants (Cobrado and Fernandez 2017).

This result proved that these antibiotics (Nystatin and Streptomycin + Nystatin) would reduce the growth of Rhizopus sp. on tissue-culture 'Lakatan' banana. Results also revealed that using of Nystatin as an antifungal on unidentified fungus suppressed its colony growth in tissue-cultured 'Lakatan' banana. Application of Nystatin with $1 \mathrm{~mL}$ $\mathrm{L}^{-1}$ is more effective compared to the other treatments.

This coincides with the study of John Innes Institute on the use of antibiotics to control infections in cultures of protoplasts of leaf mesophyll cells. The antifungal Nystatin and Amphotericin B can control fungal growth at concentration of 25 units and $2.5 \mu \mathrm{g} \mathrm{mL} \mathrm{m}^{-1}$ respectively. The most satisfactory control of contaminating microorganisms was obtained with a combination of Nystatin (25 units $\left.\mathrm{mL}^{-1}\right)$ or Amphotericin B $\left(2.5 \mu \mathrm{g} \mathrm{mL}^{-1}\right)$ and Carbenicillin $\left(250 \mu \mathrm{g} \mathrm{mL}^{-1}\right)$.

The slowest colony development at three to seven days after incubation was on the medium treated with Nystatin. Although it had minute growth, the mycelial development was not fast compared to control and all other treatments. Nystatin fixed the major component of fungal cell that forms pores in the membrane that may cause gradual death of fungus (Hammond 1977).

The results revealed that Streptomycin $\left(200 \mathrm{mg} \mathrm{L}^{-1}\right)$ and Streptomycin $\left(200 \mathrm{mg} \mathrm{L}^{-1}\right.$ + Nystatin $\left(1 \mathrm{~mL} \mathrm{~L}^{-1}\right)$ were significantly different to control as well as to chemical check which is Benomyl in terms of clear zone inhibition diameter $(\mathrm{mm})$ of bacterium.

Streptomycin is a bactericidal agent that blocks the protein synthesis and binding irreversibly the bacterial ribosomes (Chiou and Jones 1995). It binds to the small 16S rRNA of the 30S subunit of the bacterial ribosome, interfering with the binding of formyl-methionyl-tRNA to the 30 S subunit according to Sharma et al (2007). This leads to codon misreading, eventual inhibition of protein synthesis and ultimately death of microbial cells through mechanisms that are still not understood. Speculation on this mechanism indicates that the binding of the molecule to the $30 \mathrm{~S}$ subunit interferes with $50 \mathrm{~S}$ subunit association with the mRNA strand. This results in an unstable ribosomal-mRNA complex, leading to a frame shift mutation and defective protein synthesis; leading to cell death (Raymon 2011).

According to the study of Norelli et al (2003), Streptomycin remains the most reliable and commercially effective control product available against blossom 
blight stage of fire blight. It has also been frequently used in combination with Streptomycin to mitigate pathogen resistance development (Duffy et al 2005). According to Johnson and Stockwell (1998), control to a fire blight caused by Erwinia amylovora, a relative of Escherichia coli and other enteric bacteria, is the application of Streptomycin every three to four days as prophylactic treatment to limit fire blight damage during blossom time, when fire blight damage is most devastating. In addition, Vidaver $(2000,2001)$ reported that the application of Streptomycin may be used in controlling against fire blight of apple and pears.

Lastly, it was noticed that the most effective treatment that showed higher clear zone inhibition of Gram-negative Bacteria was on medium treated with Streptomycin and Streptomycin + Nystatin. After $72 \mathrm{~h}$ the increment lowers, and it implies that this antibiotic has a threshold level of effectiveness that can cause a bacterial cell to depress its growth. This therefore suggests that nystatin and streptomycin can be used as antibiotics against bacterial and fungal contaminants of tissue-cultured 'Lakatan' banana.

\section{CONCLUSION}

This study was conducted for the first time to specifically characterize the bacterial and fungal contaminants of tissue-cultured 'Lakatan' banana (Musa acuminata) and find out effective antibiotics against these contaminants. Results confirmed the effectivity of antibiotics, nystatin, and streptomycin as anti-bacterial and fungal contaminants in tissue-cultured 'Lakatan' banana.

The different contaminants occurring during the initiation stage of tissuecultured 'Lakatan' banana meriplants were composed of Rhizopus sp., an unidentified fungus, and Gram negative bacterium. These are commonly found in other tissue-culture contaminants except for the unidentified fungus with overall $35 \%$ contamination observed during initiation stage. The result further revealed that colony diameter of unidentified fungus and Rhizopus $s p$. was inhibited by Nystatin $\left(1 \mathrm{~mL} \mathrm{~L}^{-1}\right)$. Meanwhile, the bacterial clear zone inhibition was increased by Streptomycin. Hence, both Nystatin $\left(1 \mathrm{~mL} \mathrm{~L}^{-1}\right)$ and Streptomycin were effective antagonists against fungi and bacteria, respectively. This confirmed previous studies conducted on Nystatin and Streptomycin.

\section{REFERENCES}

Bauer AW, Kirby WMM, Sherris JC \& Turck M. 1966. Antibiotic susceptibility testing by a standardized single disk method. American Journal of Clinical Pathology 36(4):493-496

Cassells AC. 1996. Production of healthy plants. In Alerson PG and Dullforce WM (eds) Proceedings of the institute of horticultural symposium: micropropagation in culture (pp53-71). Nothingham, University of Nottingham Trent Print Unit

Cassells AC. 2001. Contamination and its impact in tissue culture. Acta Horticulturae 560:353-369

Chiou CS and Jones AL. 1995. Molecular analysis of high-level streptomycin resistance in Erwinia amylovora. Phytopathology 85:324-328

Cobrado $\mathrm{J}$ and Fernandez AM. 2017. Bioefficacy test of different chemotherapeutic substances against Aspergillus sp. and Chrysosporium sp. contaminants of 
In vitro efficacy of different antibiotics against contaminants of tissue-cultured

tissue-cultured abaca (Musa textiles Nee) during initial stage of micropropagation. Journal of Advances in Microbiology 4(1):1-12

Cobrado $\mathrm{J}$ and Fernandez AM. 2016. Common fungi contamination affecting tissuecultured abaca (Musa textiles Nee) during initial stage of micropropagation. Asian Research Journal of Agriculture 1(2):1-7

Damasco OP and Barba RC. 1985. In vitro culture of Saba (Musa sp. cv. Saba BBB). Philippine Agriculturist 67:351-358

Frison E and Sharrock S. 1999. The economic, social and nutritional importance of banana in the world. In Picq C, Fouré E \& Frison EA (eds) Bananas and Food Security (pp21-35). INIBAP, Montpellier, France

Habiba U, Reja S, Saha ML \& Khan MR. 2002. Endogenous bacterial contamination during in vitro culture of table banana: identification and prevention. Plant Tissue Culture 12(2):117-124

Hammond SM. 1997. Biological activity of polyene antibiotics. Progress in Medicinal Chemistry 14:105-79

Hindoy CM, Magbalot-Fernandez A, Ubaub LT \& Basu SK. 2020. Bacterial and fungal contaminants of tissue-cultured 'Lakatan' banana. International Journal on Agricultural Sciences 11(1):8-12

Hudzicki J. 2009. Kirby-Bauer disk diffusion susceptibility test protocol. American Society for Microbiology. https://asm.org/getattachment/2594ce26-bd44-47f68287-0657aa9185ad/Kirby-Bauer-Disk-Diffusion-Susceptibility-Test-Protocolpdf.pdf

Johnson K and Stockwell V. 1998. Management of fire blight: a case study in microbial ecology. Annual Review of Phytopathology 36:227-248

Leggatt IV, Waites WM, Leifert C \& Nicholas J. 1994. Characterisation of microorganisms isolated from plants during micropropagation. In ISHS Acta Horticulturae 225: Bacterial and bacteria-like contaminants of plant tissue cultures. http://www.actahort.org/books/225/index.htm

Leifert $C$ and Cassells AC. 2001. Microbial hazards in plant tissue and cell cultures. In vitro Cellular and Developmental Biology - Plant 37(2):133-138

Leifert C. 1990. Contaminants of plant tissue cultures (PhD dissertation). Notting ham University, School of Agriculture

Leifert C. 1991. Contaminants of plant-tissue and cell cultures. World Journal of Microbiology \& Biotechnology 7:452-469

Mng'omba SA, Sileshi G, du Toit ES \& Akinnifesi FK. 2012. Efficacy and utilization of fungicides and other antibiotics for aseptic plant cultures. In Dhanasekaran $D$ (ed) Fungicides for Plant and Animal Diseases. InTech. https://www.intechopen .com/chapters/26032

Norelli JL, Jones AL \& Aldwinkle HS. 2003. Fire blight management in the twentyfirst century: using new technologies that enhance resistance in apple. Plant Diseases 87(7):756-765

O'Donnel KL. 1979. Zygomycetes in culture. Palfrey Contributions in Botany No. 2. Department of Botany, University of Georgia, Athens, Georgia

Odutayo OI, Amusa NA, Okutade 00 \& Ogunsanwo YR. 2007. Sources of microbial contamination in tissue culture laboratories in southwestern. African Journal of Agricultural Research 2(3):067-072

Odutayo OI, Oso RT, Akinyemi BO \& Amusa NA. 2004. Microbial contaminants of cultured Hibiscus cannabinus and Telfaria occidentalis tissues. African Journal of Biotechnology 3(9):473-476 
Omamor IB, Asemota AO, Eke CR \& Eziashi El. 2007. Fungal contaminants of the oil palm tissue culture in Nigerian Institute for Oil Palm Research (NIFOR). African Journal of Agricultural Research 2(10):534-537

Philippine Council for Agriculture, Forestry and Resources Development (PCARRD). 1988. Philippines recommends for banana. Philippine Council for Agriculture, Forestry and Resources Development. Department of Science and Technology, Philippines

Philippine Council for Agriculture, Forestry and Resources Development (PCARRD). 2004. Banana Production Manual. Philippine Council for Agriculture, Forestry and Resources Development. Department of Science and Technology, Philippines

Raymon LP. 2011. Complex level 1: pharmacological lecture notes. Kaplan Medical, Kaplan Inc. New York, USA

Reed BM, Buckley PM \& Dewilde TN. 1995. Detection and eradication of endophytic bacteria from micro propagated mint plants. In vitro Cellular and Developmental Biology - Plant 31(1):53-57

Sharma D, Cukras AR, Rogers EJ, Southworth DR \& Green R. 2007. Mutational analysis of protein and implication for the accuracy of decoding by the ribosome. Journal of Molecular Biology 374(4):1065-76

Vidaver AK. 2001. Horticultural and other uses of antibiotics. In Soulsby L, Wilbur R (eds) Antimicrobial resistance (pp.125-30). Proceedings of the Royal Society of Medicine Symposium. RSM Press, Washington, DC

Vidaver AK. 2002. Uses of antibiotics in plant agriculture. Clinical Infection Diseases 34(Supplement 3):107-110

Vuylsteke D and De Langhe EA. 1985. Feasibility of in vitro propagation of banana and plantains. Tropical Agriculture (Trinidad) 62(4):323-328

Wallace TL and Lopez-Berestein G. 1997. Nystatin and liposomal nystatin. In Yu VL, Merigan TC, Barriere S \& White NJ (eds) Antimicrobial Therapy and Vaccines (pp1185-1191). Williams \& Wilkins, Baltimore, MD

World Trade Organization (WTO). 2006. International trade statistics 2006. https://www.wto.org/english/res_e/statis_e/its2006_e/its2006_e.pdf 